\title{
Transverse testicular ectopia with persistent mullerian duct syndrome
}

\author{
Archit Gupta, Prince Raj, Rajinder Singh Jhobta
}

Department of Surgery, Indira Gandhi Medical College, Shimla, India

\section{Correspondence to}

Dr Archit Gupta archit9th@gmail.com

Accepted 6 April 2018
Check for updates

To cite: Gupta A, Raj P, Jhobta RS. BMJ Case Rep Published Online First: [please include Day Month Year]. doi:10.1136/bcr-2017223994

\section{SUMMARY}

Persistent mullerian duct syndrome (PMDS) is a rare form of male pseudohermaphroditism caused by defects in synthesis or actions of mullerian inhibiting factor characterised by persistence of mullerian duct structures in a normal karyotype male. Transverse testicular ectopia (TTE) is a rare disease in which both testes are located in the same inguinal canal. We report a case of PMDS with TTE in a 1-year-old child who presented with nonpalpable testis on right side with hernia on left side. Left herniotomy with bilateral trans-septal orchidopexy was done in this patient.

\section{BACKGROUND}

Persistent mullerian duct syndrome (PMDS) is a form of male disorder of sexual differentiation with persistence of mullerian duct structures characterised by the presence of uterus and fallopian tubes in a phenotypically and genotypically normal male. ${ }^{1}$ Transverse testicular ectopia (TTE) is a rare form of testicular ectopia in which both testes are located in the same inguinal canal. We report a case of PMDS with TTE in a 1-year-old child.

\section{CASE PRESENTATION}

A 1-year-old male child presented to surgery outpatient department with complaints of swelling in left inguinal region and absent right testis since birth. The child was born by a full-term normal vaginal delivery. There was no history of any other congenital anomaly and was adequately immunised. There was no history of undescended testes or any congenital anomaly in the family. On examination, a swelling of size $1 \times 1 \mathrm{~cm}$ was present in left inguinal region. Swelling was more apparent on standing or crying. Right testis was not palpable. There was no developmental delay and examination of other systems was within normal limits.

\section{INVESTIGATIONS}

Haemoglobin was $11.1 \mathrm{~g} / \mathrm{dL}$. Total leucocyte count was $6500 / \mathrm{mm}^{3}$.

\section{TREATMENT}

The patient was taken up for elective surgery with a diagnosis of left congenital hernia with right undescended testis. On exploration, left hernia sac had mullerian duct remnant with both the testes (figure 1). Left herniotomy with bilateral transseptal subdartos orchidopexy was done under general anaesthesia.

\section{OUTCOME AND FOLLOW-UP}

Postoperative period was uneventful and the patient was discharged on postoperative day 2 .

\section{DISCUSSION}

TTE is a rare form of ectopic testes. TTE was first reported as a finding at autopsy by Von Lenhossek in $1886 .^{2}$

PMDS is caused by defects in synthesis or actions of mullerian inhibiting factor. ${ }^{3}$ It is characterised by normal male karyotype with persistent mullerian duct derivatives.

Jordan described TTE with PMDS for the first time in $1895 .^{2}$ PMDS with TTE is a rare anomaly that is usually encountered at the time of laparoscopy or while exploring for inguinal hernia. This anomaly combines abnormal testicular descent with regression of fetal mullerian structures.

Hutson et al classified PMDS into three groups. ${ }^{1}$ Group A is the female type where testes are in position of normal ovaries. Group B is the male type with one testis in hernial sac or scrotum with the uterus and tubes. Group C is also male type with both testes found in same hernial sac with associated tubes and uterus. Our patient was Group C PMDS.

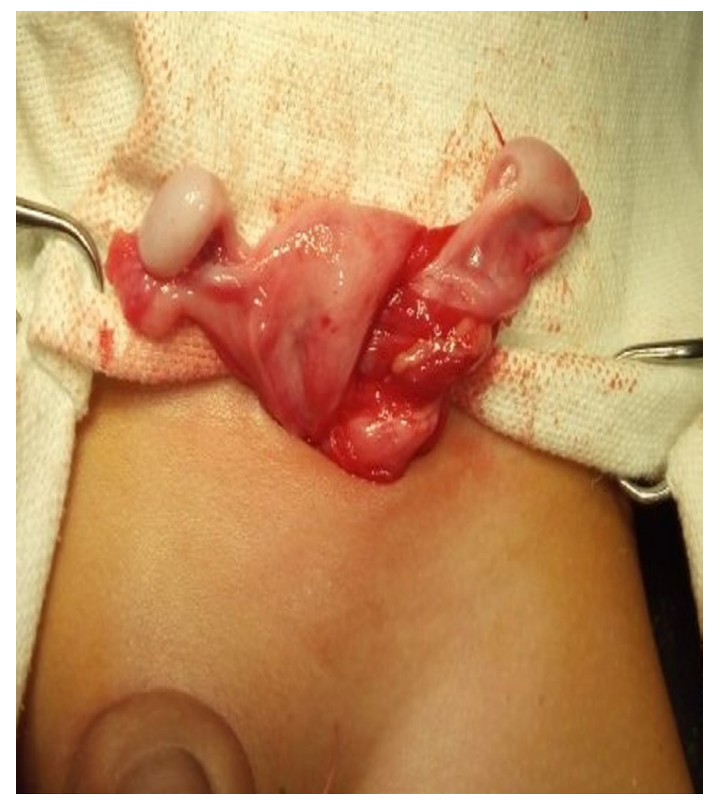

Figure 1 Intraoperative picture showing bilateral testes in the same inguinal canal with persistent mullerian duct structures. 
Most of the patients are diagnosed at the time of surgery. However, ultrasonography and MRI help in diagnosing it preoperatively. Hormonal assessment is not done routinely. ${ }^{4}$

In our case, imaging was not done and patient was taken for upfront surgery.

Treatment of PMDS is surgical and involves correction of cryptorchidism. Various methods have been described like fixation of testes on opposite side through suprapubic subcutaneous tunnel or herniotomy with trans-septal fixation of testes. ${ }^{5}$

Orchidectomy can be done if testes cannot be mobilised or if there is a risk of malignancy. Orchidectomy should be followed by lifelong supplementation of testosterone.

Laparoscopy can be used for diagnosis and management of undescended testes. Kamble et $a l^{1}$ were the first to describe total laparoscopic repair for TTE with PMDS in 2015. Laparoscopy is now becoming the route of choice for management of such cases.

There are reports of seminoma, embryonal cell carcinoma, clear cell adenocarcinoma and yolk sac tumours in patients with PMDS. ${ }^{6}$ However, recent studies suggest the incidence of these is similar to that of a normal cryptorchid child. ${ }^{7}$

Removal of persistent mullerian duct structures is associated with high rate of injury to vas deferens. Hysterectomy is only

\section{Learning points}

- Persistent mullerian duct syndrome with transverse testicular ectopia is a rare anomaly which combines abnormal testicular descent with failure of regression of fetal mullerian structures.

- Diagnosis is usually made at the time of surgery.

- Treatment involves correction of cryptorchidism.

- Removal of persistent mullerian structures is not mandatory and is associated with high rate of injury to vas deferens. indicated when these structures limit the placement of testes in scrotum. ${ }^{8}$

In our case, herniotomy with trans-septal fixation of testes was done and the patient was kept on follow-up.

Contributors PR has done definition of intellectual content and manuscript review. AG has searched the literature and prepared the manuscript and RSJ did manuscript editing.

Funding The authors have not declared a specific grant for this research from any funding agency in the public, commercial or not-for-profit sectors.

Competing interests None declared.

Patient consent Parental/guardian consent obtained.

Provenance and peer review Not commissioned; externally peer reviewed. (C) BMJ Publishing Group Ltd (unless otherwise stated in the text of the article) 2018. All rights reserved. No commercial use is permitted unless otherwise expressly granted.

\section{REFERENCES}

1 Kamble RS, Gupta RK, Gupta AR, et al. Laparoscopic management of transverse testicular ectopia with persistent mullerian duct syndrome. J Minim Access Surg 2015;11:213-5.

2 Von Lenhossek M. Ectopia testis transversa. Anat Anz 1886;1:376.

3 Gujar NN, Choudhari RK, Choudhari GR, et al. Male form of persistent Mullerian duct syndrome type I (hernia uteri inguinalis) presenting as an obstructed inguinal hernia: a case report. J Med Case Rep 2011;5:586.

4 Berkmen F. Persistent müllerian duct syndrome with or without transverse testicular ectopia and testis tumours. Br J Urol 1997;79:122-6.

5 Telli O, Gökçe MI, Haciyev P, et al. Transverse testicular ectopia: a rare presentation with persistent Müllerian duct syndrome. J Clin Res Pediatr Endocrinol 2014;6:180-2.

6 Shinmura Y, Yokoi T, Tsutsui Y. A case of clear cell adenocarcinoma of the müllerian duct in persistent müllerian duct syndrome: the first reported case. Am J Surg Pathol 2002;26:1231-4.

7 Farikullah J, Ehtisham S, Nappo S, et al. Persistent Müllerian duct syndrome: lessons learned from managing a series of eight patients over a 10-year period and review of literature regarding malignant risk from the Müllerian remnants. BJU Int 2012;110:E10 84-E1089.

8 Kumar PN, Venugopala K. Persistent mullerian duct syndrome with transverse testicular ectopia. J Surg Tech Case Rep 2015;7:4-6.

Copyright 2018 BMJ Publishing Group. All rights reserved. For permission to reuse any of this content visit

http://group.bmj.com/group/rights-licensing/permissions.

BMJ Case Report Fellows may re-use this article for personal use and teaching without any further permission.

Become a Fellow of BMJ Case Reports today and you can:

- Submit as many cases as you like

- Enjoy fast sympathetic peer review and rapid publication of accepted articles

- Access all the published articles

- Re-use any of the published material for personal use and teaching without further permission

For information on Institutional Fellowships contact consortiasales@bmjgroup.com

Visit casereports.bmj.com for more articles like this and to become a Fellow 